\section{RSP}

http://www.rsp.fsp.usp.br/
Revista de Saúde Pública

\title{
Cost effectiveness of the cancer prevention program for carriers of the BRCA1/2 mutation
}

\author{
Marcelo Cristiano de Azevedo Ramos', Maria Aparecida Azevedo Koike Folgueira", Simone \\ Maistro", Alessandro Gonçalves Campolina", Patricia Coelho de Soárez"II, Geertruida Hendrika de \\ Bock $^{\mathrm{IV}}$, Hillegonda Maria Dutilh Novaes"', Maria Del Pilar Estevez Diz ${ }^{\mathrm{V}}$ \\ I Universidade de São Paulo. Faculdade de Medicina. Hospital das Clínicas. Instituto Central. Diretoria \\ Executiva. São Paulo, SP, Brasil \\ " Universidade de São Paulo. Faculdade de Medicina. Hospital das Clínicas. Instituto do Câncer do Estado de \\ São Paulo. Centro de Investigação Translacional em Oncologia. São Paulo, SP, Brasil \\ III Universidade de São Paulo. Faculdade de Medicina. Departamento de Medicina Preventiva. São Paulo, SP, Brasil \\ Iv University of Groningen. University Medical Center Groningen. Department of Epidemiology. Groningen, \\ The Netherlands \\ $\checkmark$ Universidade de São Paulo. Faculdade de Medicina. Hospital das Clínicas. Instituto do Câncer do Estado de \\ São Paulo. Divisão de Oncologia Clínica. São Paulo, SP, Brasil
}

\section{Correspondence:}

Marcelo Cristiano de Azevedo Ramos Hospital das Clínicas - FMUSP Av. Dr. Enéas de Carvalho Aguiar, 255 sala 5013

05403-000 São Paulo, SP, Brasil E-mail: marcelo.azevedo@hc.fm.usp.br

Received: Dec 21, 2017

Approved: Apr 4, 2018

How to cite: Ramos MCA Folgueira MAAK, Maistro S, Campolina AG, Soárez PC, Bock $\mathrm{GH}$, et al. Cost effectiveness of the cancer prevention program for carriers of the BRCA1/2 mutation. Rev Saude Publica. 2018;52:94.

Copyright: This is an open-access article distributed under the terms of the Creative Commons Attribution License, which permits unrestricted use, distribution, and reproduction in any medium, provided that the original author and source are credited.

\section{ABSTRACT}

OBJECTIVE: To analyze the cost effectiveness of the diagnostic program for the germline mutation in $B R C A 1 / 2$ genes and of preventative strategies for the relatives of patients diagnosed with ovarian cancer associated with this mutation.

METHODS: The study analyzed the cost effectiveness by developing an analysis of the Markov decision process from the perspective of the National Health System. The strategies compared reflect upon the adoption of genetic testing and preventative strategies for relatives or the usual care currently proposed. The incremental cost-effectiveness ratio was expressed in terms of cost per case avoided. The sensitivity analysis was performed in a univariate and deterministic manner.

RESULTS: The study showed increments for effectiveness and for costs when performing genetic testing and adopting prophylactic measures for family members. The incremental cost-effectiveness ratio was estimated at $\mathrm{R} \$ 908.58$ per case of cancer avoided, a figure considered lower than the study's cost-effectiveness threshold ( $\mathrm{R} \$ 7,543.50)$.

CONCLUSIONS: The program analyzed should be considered a cost-effective strategy for the national situation. Studies in various other countries have reached similar conclusions. One possible ramification of this research might the need to perform a budgetary-impact analysis of making the program one of the country's health policies.

DESCRIPTORS: Ovarian Neoplasms, diagnosis. Genes, BRCA1. Genes, BRCA2. Early Detection of Cancer, economics. Cost-Effectiveness Evaluation. 


\section{INTRODUCTION}

According to data provided by the National Cancer Institute, around 6,150 new cases of ovarian cancer are recorded every year in Brazil ${ }^{1}$. Although this neoplasm only makes up a small proportion of the cases of malignancies diagnosed in the country, at the moment, it has the second highest mortality rate for all gynecological tumors².

One of the main risk factors associated with the development of this neoplasm is genetic predisposition ${ }^{3,4}$. Hereditary breast and ovarian cancer syndrome, which is related to mutations in the BRCA1 and BRCA2 genes, is an important cause of ovarian carcinoma. It is present in $15 \%$ to $19 \%$ of all cases ${ }^{5,6}$. Germline $B R C A 1 / 2$ mutation testing is not currently funded by the National Health System, and the estimated prevalence rate of this mutation in Brazil is similar to several other studies.

Because of the strong association between ovarian carcinoma and germline mutation, different professional bodies have recommended counselling and genetic testing for any woman who develops a malignant tumor ${ }^{7,8}$. The benefit of testing is that the mutation significantly increases the risk of a second primary cancer and frequently affects the choice of treatment ${ }^{9}$. Performing a diagnostic exam also allows family members who carry the germline mutation to be identified, so they can be offered risk-reduction therapy ${ }^{9}$. The current recommendation to manage risk in women who are carriers of a mutation in the $B R C A 1$ and BRCA2 genes consists of offering risk-reducing salpingo-oophoerectomy and bilateral prophylactic mastectomy ${ }^{7,10}$.

Therefore, the objective of this study was to analyze the cost effectiveness of the program for diagnosing the germline mutation in the BRCA1/2 genes and of the preventative strategies offered to the relatives of patients who develop ovarian cancer.

\section{METHODS}

\section{General Characteristics of the Study}

The study analyzed the cost effectiveness of the program that diagnoses germline mutations in the $B R C A 1 / 2$ genes and of preventative strategies offered to the relatives of patients with ovarian cancer associated with this mutation. Germline mutation was already confirmed in these ovarian cancer patients, being either BRCA1 or BRCA2.

The perspective from the National Health System in the federal domain (Ministry of Health) was selected. The model of analysis for the decision adopted corresponded with the Markov model. This type of model was chosen because of the longer horizontal follow-up period and because of the need to simulate the transition between different states of health across fixed intervals of time. Figure 1 shows a consolidated version of the model proposed for this study.

The alternatives compared herein consisted of performing genetic tests on first-degree female family members of patients who have ovarian cancer and the germline mutation or the usual care currently proposed. In the group of family members who, hypothetically, underwent genetic testing, the simulation strategy consisted of offering risk-reducing salpingo-oophorectomy and bilateral prophylactic mastectomy when the germline mutation was present in the $B R C A 1 / 2$ genes. When mastectomy was refused, we simulated annual follow-up by complementary exams (magnetic resonance imaging of the breasts and a bilateral mammogram). The model did not adopt conducts aiming the early diagnosis of ovarian cancer, in situations where the salpingo-oophorectomy was refused, since the tracking methods currently available are not effective for this purpose ${ }^{11}$. No prophylactic conduct was simulated for family members without the germline mutation in the BRCA1/2 genes. For each trajectory described, we simulated the possibility of subsequent development of malignant neoplasms of the breasts and ovaries. 


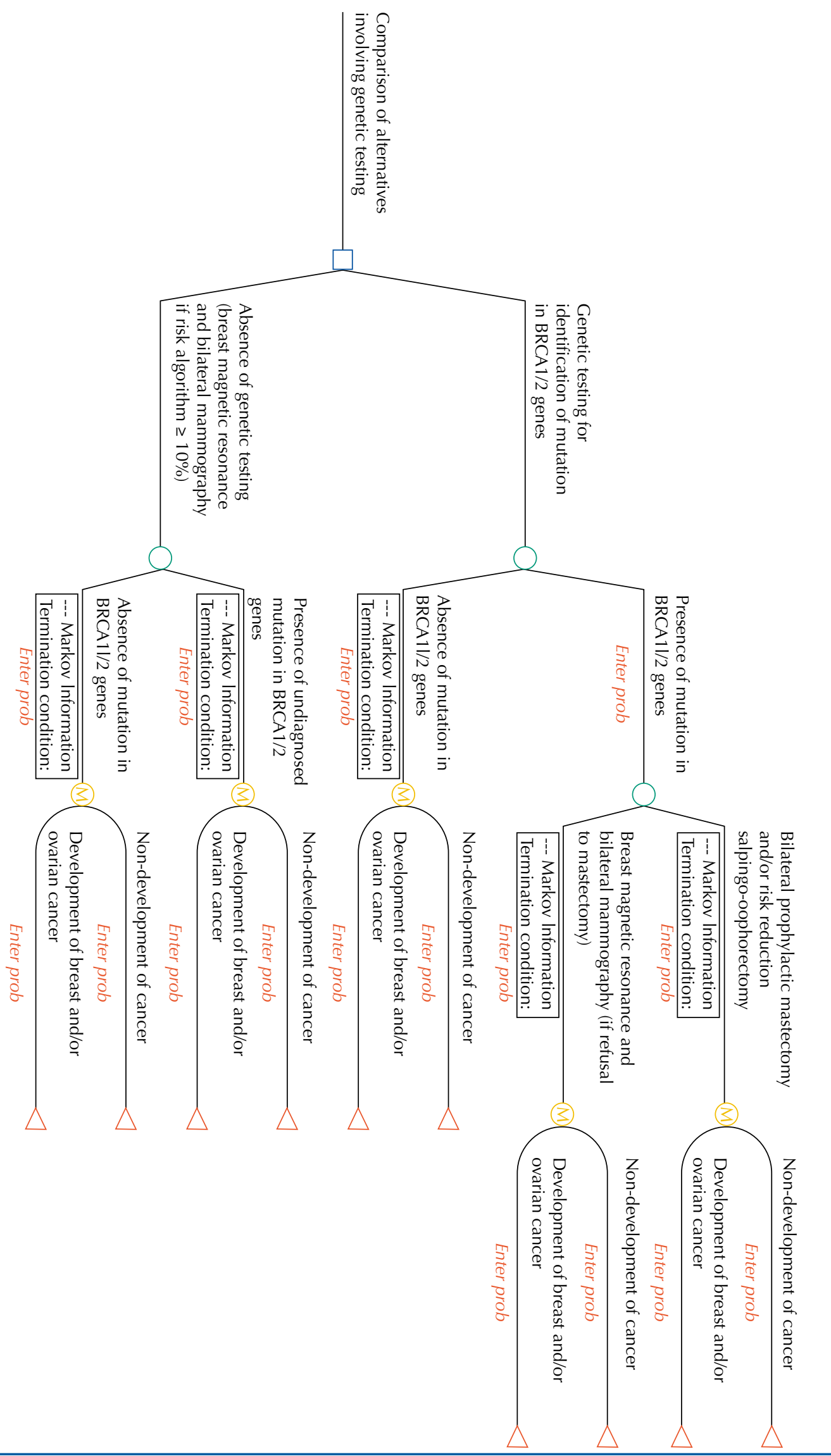

Figure 1. Markov model for strategies involving relatives of patients with ovarian cancer.

In the group that, hypothetically, did not undergo genetic testing, annual follow-up with magnetic resonance imaging of the breasts and a bilateral mammogram were simulated when the algorithm of risk for the germline mutation was equal to or greater than $10 \%$. No 
additional conduct was simulated when the algorithm of risk for mutation was lower than $10 \%$. In addition, for each of the trajectories described, we represented the possibility of subsequent development of breast and ovarian cancers.

The model's temporal horizon extended from 30 to 70 years of age, with annual cycles to evaluate any transition in states and the development of cancer. Neither the age at which $B R C A 1 / 2$ testing was done nor the age at which risk-reducing salpingo-oophorectomy and bilateral prophylactic mastectomy were performed varied (30 years-old).

We adopted the following premises for this model: no family member had previously undergone genetic testing nor had a prior diagnosis of malignant breast and ovarian neoplasms, and family members who were not carriers of mutations in the BRCA1/2 genes had the same risk as the general population for the development of malignant breast and ovarian neoplasms.

\section{Definition of the Estimates of Effectiveness}

The definition of effectiveness was cancer cases prevented, discounted at 5\%.

An umbrella research project provided demographic data, results related to the application of the algorithms of risk, and information about the prevalence of germline mutations in patients diagnosed with ovarian cancer in Brazil ${ }^{6,12}$.

Information related to the possible adherence to preventative strategies, penetrance of the germline mutations in the $B R C A 1 / 2$ genes, and the reduction of risk in the development of neoplasm by prophylactic surgery were obtained based on research in the PubMed database. In addition, we performed an electronic search for studies that did an economic evaluation of germline mutation in the $B R C A 1$ and $B R C A 2$ genes.

\section{Definition of the Estimates of Costs}

The costs of genetic testing were defined based on commercial proposals received from manufacturers or local distributors. The monetary value in dollars or euros was converted into the Brazilian currency, based on the average quotations for the year 2014 (R $\$ 2.35$ and $\mathrm{R} \$ 3.12$, respectively $)^{13}$. The estimations involved measuring the costs for next-generation sequencing and for multiplex ligation-dependent probe amplification.

The sums involved in the program to reduce the risk of malignant neoplasm were defined by a panel composed of specialists and the hospital's clinical guidelines. The definition of costs involved the macro-costing method. The unit values corresponded to those described in the Table of Procedures, Medications and Ortheses, Prostheses, and Special Materials for the National Health System ${ }^{14}$. This reference point was chosen because it corresponds to the main component of health financing in Brazil, incorporating different geographic situations and health providers. Moreover, adopting a single pattern might help alleviate eventual distortions and discrepancies in the Table's values.

All data for the costs was presented in Brazilian Real for 2014. The annual discount rate for the costs adopted in the study was 5\%, in line with the Guideline Methods for Economic Evaluation published by the Ministry of Health ${ }^{15}$.

\section{Demonstration of the Results and Sensitivity Analysis}

Estimation and demonstration of the results of the economic evaluation were performed using the TreeAge Pro ${ }^{\circledR}$ sotfware, version 2017 (TreeAge Software Inc. Williamstown, Massachusetts). For each strategy compared, the anticipated costs and respective effectiveness were presented. The ratio of incremental cost effectiveness, estimated based on the mathematical ratio between the increment of costs and the increment of effectiveness, was expressed in terms of cost per case prevented. As a comparative reference, we used the 
cost-effectiveness thresholds developed by the Center for Health Economics at the University of York ( $\$ 7,543.50$ to $\mathrm{R} \$ 23,786.70)^{16}$.

We performed the sensitivity analysis in a deterministic and univariate manner. This analysis consisted of an individual evaluation of the main parameters of this study, while the others remained constant. The analysis was presented in graph form as a Tornado Diagram. The references for variability resulted in values for the $95 \%$ confidence interval for the parameters.

\section{RESULTS}

The proportion of patients diagnosed with ovarian cancer and the germline mutation found in the project was $17 \%$ with the $B R C A 1$ gene and $2 \%$ with the BRCA2 gene ${ }^{6}$. Given that the transmission of the mutation in autosomal dominant inheritance is $50 \%$, the proportion of family members was estimated at $45 \%$ for carriers of the $B R C A 1$ gene mutation, $5 \%$ for carriers of the $B R C A 2$ gene mutation, and $50 \%$ for those without the mutation.

Penetrance of the mutations involving the $B R C A 1$ gene and breast cancer is more expressive than that for the $B R C A 2$ gene and ovarian cancer ${ }^{17}$. In fact, the probability of developing breast cancer is more prominent in the presence of a germline mutation in BRCA1 (57\%) than in BRCA2 (49\%) ${ }^{17}$. A similar situation occurs, though less often, for ovarian cancer, in which the probability of developing cancer is higher among carriers of a germline mutation in the $B R C A 1$ gene (40\%) than among carriers of a germline mutation in the $B R C A 2$ gene $(18 \%)^{17}$.

The parameters for adherence to risk-reducing surgeries and the impact of performing them on the future development of breast and ovarian cancer have also been determined ${ }^{17-20}$.

Table 1. Probabilities used in the decision model.

\begin{tabular}{|c|c|c|c|}
\hline Description & Estimate & Range & Reference \\
\hline Probability of mutation in $B R C A 1$ gene & 0.45 & - & Maistro et al. ${ }^{6}(2016)$ \\
\hline Probability of mutation in $B R C A 2$ gene & 0.05 & - & Maistro et al. ${ }^{6}(2016)$ \\
\hline Probability of adherence to bilateral prophylactic mastectomy & 0.57 & $0.47-0.66$ & Chen et al. ${ }^{17}(2007)$ \\
\hline Probability of adherence to risk reduction salpingo-oophorectomy & 0.49 & $0.40-0.57$ & Chen et al. ${ }^{17}(2007)$ \\
\hline Probability of developing breast cancer in the absence of mutation in $B R C A 1 / 2$ genes & 0.06 & $0.03-0.08$ & Ferlay et al. ${ }^{30}(2013)$ \\
\hline $\begin{array}{l}\text { Probability of developing ovarian cancer in } B R C A 1 \text { mutation carrier, in the absence of } \\
\text { prophylactic surgery }\end{array}$ & 0.40 & $0.35-0.46$ & Chen et al. ${ }^{17}(2007)$ \\
\hline $\begin{array}{l}\text { Probability of developing ovarian cancer in } B R C A 2 \text { mutation carrier, in the absence of } \\
\text { prophylactic surgery }\end{array}$ & 0.18 & $0.13-0.23$ & Chen et al. ${ }^{17}(2007)$ \\
\hline Probability of developing ovarian cancer in the absence of mutation in $B R C A 1 / 2$ genes & 0.006 & $0.005-0.01$ & Ferlay et al. ${ }^{30}(2013)$ \\
\hline Probability of adherence to bilateral prophylactic mastectomy & 0.18 & $0.16-0.20$ & Metcalfe et al. ${ }^{18}(2008)$ \\
\hline Probability of adherence to risk reduction salpingo-oophorectomy & 0.57 & $0.55-0.59$ & Metcalfe et al..$^{18}(2008)$ \\
\hline Probability of developing breast cancer in $B R C A 1$ mutation carrier, after mastectomy & 0.04 & $0.03-0.05$ & $\begin{array}{l}\text { De Felice et al. }{ }^{19}(2015) \text {; Chen } \\
\text { et al. }{ }^{17}(2007)\end{array}$ \\
\hline Probability of developing breast cancer in $B R C A 2$ mutation carrier, after mastectomy & 0.03 & $0.03-0.04$ & $\begin{array}{l}\text { De Felice et al. }{ }^{19}(2015) \text {; Chen } \\
\text { et al. } .^{7}(2007)\end{array}$ \\
\hline $\begin{array}{l}\text { Probability of developing breast cancer in BRCA1 mutation carrier, after } \\
\text { salpingo-oophorectomy }\end{array}$ & 0.28 & $0.23-0.32$ & $\begin{array}{l}\text { Rebbeck et al. } .^{20}(2009) ; \text { Chen } \\
\text { et al. } .^{7}(2007)\end{array}$ \\
\hline $\begin{array}{l}\text { Probability of developing breast cancer in } B R C A 2 \text { mutation carrier, after } \\
\text { salpingo-oophorectomy }\end{array}$ & 0.24 & $0.20-0.28$ & $\begin{array}{l}\text { Rebbeck et al. } .^{20}(2009) \text {; Chen } \\
\quad \text { et al. } .^{7}(2007)\end{array}$ \\
\hline $\begin{array}{l}\text { Probability of developing breast cancer in } B R C A 1 \text { mutation carrier, after mastectomy and } \\
\text { salpingo-oophorectomy }\end{array}$ & 0.02 & $0.01-0.03$ & $\begin{array}{l}\text { De Felice et al. } .^{19}(2015) \text {; Rebbeck } \\
\text { et al. }{ }^{20}(2009) ; \text { Chen et al. } .^{.7}(2007)\end{array}$ \\
\hline $\begin{array}{l}\text { Probability of developing breast cancer in } B R C A 2 \text { mutation carrier, after mastectomy and } \\
\text { salpingo-oophorectomy }\end{array}$ & 0.02 & $0.01-0.02$ & $\begin{array}{l}\text { De Felice et al. } .^{19} \text { (2015); Rebbeck } \\
\text { et al. } .^{20}(2009) ; \text { Chen et al. } .^{17}(2007)\end{array}$ \\
\hline $\begin{array}{l}\text { Probability of developing ovarian cancer in BRCA1 mutation carrier, after } \\
\text { salpingo-oophorectomy }\end{array}$ & 0.08 & $0.07-0.10$ & $\begin{array}{l}\text { Rebbeck et al. } .^{20}(2009) ; \text { Chen } \\
\text { et al. } .^{17}(2007)\end{array}$ \\
\hline $\begin{array}{l}\text { Probability of developing ovarian cancer in BRCA2 mutation carrier, after } \\
\text { salpingo-oophorectomy }\end{array}$ & 0.04 & $0.03-0.05$ & $\begin{array}{l}\text { Rebbeck et al. } .^{20}(2009) \text {; Chen } \\
\text { et al. } .^{7}(2007)\end{array}$ \\
\hline
\end{tabular}


The costs involved next-generation sequencing and the evaluation of multiplex ligation-dependent probe amplification totaling $\mathrm{R} \$ 683.61$. The risk-reducing surgical procedures had the billing charges listed in the Table of Procedures, Medications, Ortheses, Prostheses and Special Materials of the National Health System.

The cost of screening for breast cancer in patients with a germline mutation in the $B R C A 1 / 2$ genes totaled $\mathrm{R} \$ 333.75$ per year. For family members who did not have genetic testing,

Table 2. Cost estimates used in the decision model.

\begin{tabular}{lc}
\hline Description & Cost \\
\hline Genetic counseling consultations & $\mathrm{R} \$ 200.00$ \\
$\begin{array}{l}\text { Next generation sequencing and evaluation for large genomic rearrangements } \\
\text { Bilateral prophylactic mastectomy }\end{array}$ & $\mathrm{R} \$ 683.61$ \\
$\begin{array}{l}\text { Risk-reducing salpingo-oophorectomy } \\
\text { Breast magnetic resonance imaging and bilateral mammography, in the presence of } \\
B R C A 1 / 2 \text { germline mutation and refusal to mastectomy (annual cost) }\end{array}$ & $\mathrm{R} \$ 542.46$ \\
$\begin{array}{l}\text { Breast magnetic resonance imaging and bilateral mammography, in the presence of risk } \\
\text { algorithm } \geq 10 \% \text { (annual cost) }\end{array}$ & $\mathrm{R} \$ 333.75$ \\
\hline
\end{tabular}

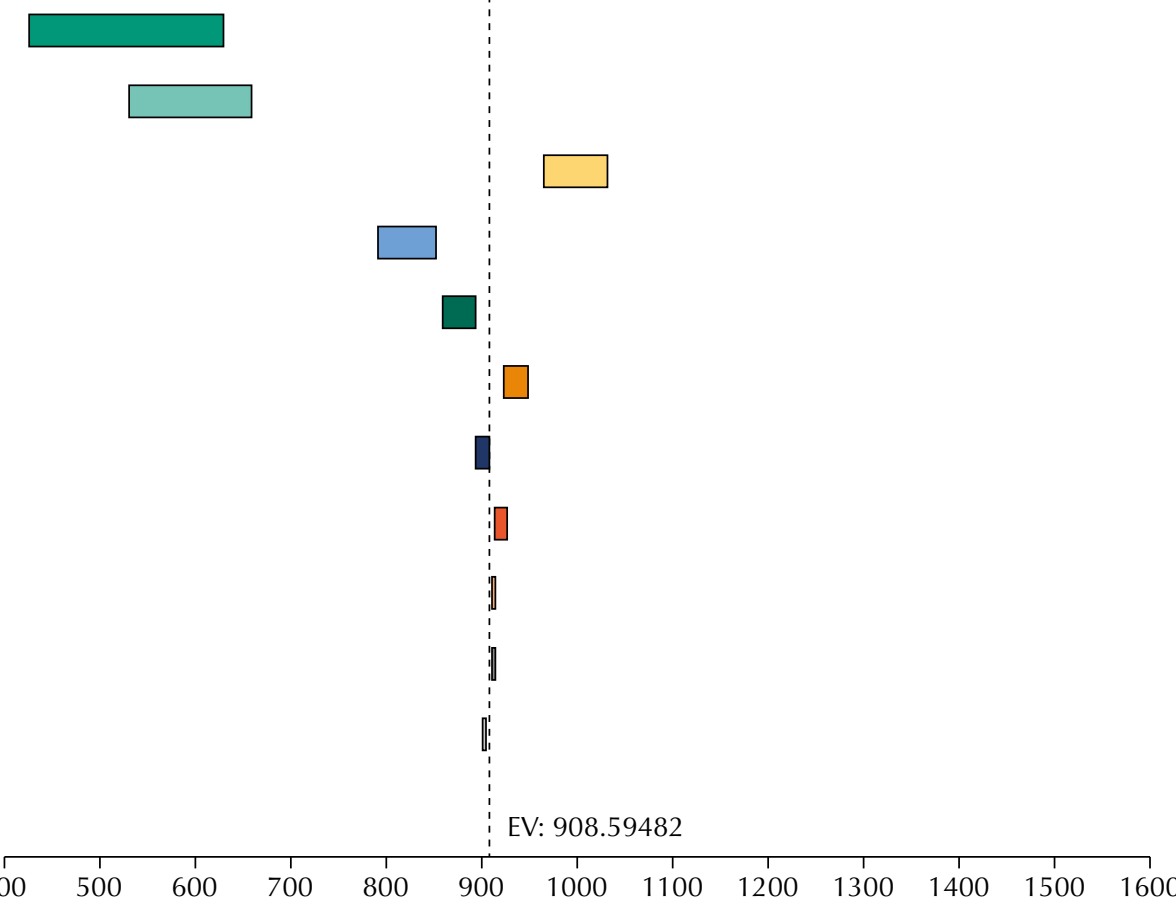

\footnotetext{
Probability of breast cancer in $B R C A 1$ mutation carrier, after magnetic resonance and mammography Probability of ovarian cancer in BRCA1 mutation carrier, in the absence of screening

Probability of breast cancer in undiagnosed BRCA1 mutation

Probability of ovarian cancer in undiagnosed $B R C A 1$ mutation

Probability of ovarian cancer in BRCA1 mutation carrier, after salpingo-oophorectomy

Probability of breast cancer in undiagnosed $B R C A 2$ mutation

Probability of ovarian cancer in undiagnosed $B R C A 2$ mutation

Probability of breast cancer in $B R C A 2$ mutation carrier, after magnetic resonance and mammography

Probability of breast cancer in the absence of mutation in BRCA1/2 genes

Probability of ovarian cancer in $B R C A 2$ mutation carrier, in the absence of screening

Probability of ovarian cancer in $B R C A 2$ mutation carrier, after salpingo-oophorectomy
}

Figure 2. Tornado Diagram related to incremental cost-effectiveness ratio. 
Table 3. Costs of ovarian cancer treatment by year.

\begin{tabular}{lcc}
\hline Year & Mean cost & $\mathbf{9 5 \% C I}$ \\
\hline 1st & $\mathrm{R} \$ 12,958.48$ & $\mathrm{R} \$ 11,504.42-\mathrm{R} \$ 14,412.54$ \\
2nd & $\mathrm{R} \$ 3,960.10$ & $\mathrm{R} \$ 2,783.99-\mathrm{R} \$ 5,136.22$ \\
3rd & $\mathrm{R} \$ 4,860.90$ & $\mathrm{R} \$ 3,597.02-\mathrm{R} \$ 6,124.78$ \\
4th & $\mathrm{R} \$ 4,167.97$ & $\mathrm{R} \$ 2,934.69-\mathrm{R} \$ 5,401.24$ \\
5th & $\mathrm{R} \$ 3,508.02$ & $\mathrm{R} \$ 1,993.53-\mathrm{R} \$ 5,022.51$ \\
\hline
\end{tabular}

annual expenditure was represented by the product of the probability of being at high risk for the mutation (24\%) and the cost of screening $(\mathrm{R} \$ 333.75)$, yielding a result of $\mathrm{R} \$ 80.10$.

Thus, based on the definition of the estimates of effectiveness and of the costs, we proceeded to develop Tables 1 and 2, which consolidate the parameters used in the model.

The program to diagnose germline mutation and preventative strategies involving family members of patients with ovarian cancer proved to be cost effective, compared with the lowest threshold of cost effectiveness adopted ( $\mathrm{R} \$ 7,543.50)$. In fact, although the program had a higher cost $(\mathrm{R} \$ 1,241.22$ versus $\mathrm{R} \$ 78.96)$, its effectiveness was better ( $\mathrm{R} \$ 16.13$ versus $\mathrm{R} \$ 14.85)$ than the strategy involving no genetic testing. Thus, the ratio of incremental cost effectiveness was estimated at $\mathrm{R} \$ 908.59$ per case of cancer prevented.

The Tornado Diagram showed that the parameters with the greatest influence on the model's results, during the univariate sensitivity analysis, were penetrance of the mutation in the $B R C A 1$ gene and the impact of not performing prophylactic surgeries. Individual variation in these parameters did not change the incremental cost-effectiveness ratio in an expressive way, so that the technology remained cost effective. Figure 2 illustrates this situation.

Finally, the number of family members eligible for the strategy, per year, was estimated at 2,045 individuals $(6,150$ cases of ovarian cancer per year multiplied by $19 \%$ of these cases related to $B R C A 1 / 2$ germline mutation multiplied by 3.5 first-degree female relatives per patient with ovarian cancer, multiplied by $50 \%$ probability of transmission of the mutation).

\section{DISCUSSION}

The program for diagnosing a germline mutation in the $B R C A 1 / 2$ genes and for preventative strategies, aimed at family members of patients diagnosed with ovarian cancer, proved to be a cost-effective alternative, from the perspective of the National Health System. It is a strategy located in quadrant I of the cost-effectiveness plan, consisting of a more effective and more costly intervention $^{21}$. In this case, the comparison between the incremental cost-effectiveness ratio and the cost-effectiveness threshold proved favorable to the adoption of the program.

In addition, the cost per case of cancer prevented (R\$08.59) was lower than the amounts typically spent on treating the cancer. In fact, data from our cohort of patients with ovarian cancer had more expressive billing figures (Table 3), over a period of five years of tracking, with palliative chemotherapy as the main driver of costs. In this respect, adopting prophylactic strategies for carriers of a germline mutation in the $B R C A 1 / 2$ genes could reduce costs and need for palliation in cases of tumor progression.

The indication of genetic testing for patients with ovarian cancer and the subsequent adoption of preventative strategies for family members carrying the germline mutation was also the motive behind a North American study ${ }^{22}$. This study concluded that testing all cases of ovarian cancer could be prohibitively expensive in comparison with the cost-effectiveness threshold adopted in the United States ${ }^{22}$. On the other hand, restricting the test to situations of prior personal history of breast cancer, family history of malignant breast and ovarian neoplasms or Ashkenazi Jewish background showed cost-effective results ${ }^{22}$. 
In this context, different studies emphasize evaluation, at the level of population, of preventative strategies for people with a higher risk of having a germline mutation ${ }^{23-26}$ One of these publications, analyzing conduct for individuals with a predictive algorithm of risk for the $B R C A 1 / 2$ mutation equal to or higher than $10 \%$, proved inconclusive regarding the use of technology, since the costs and effects of the alternatives adopted are similar to not having genetic testing ${ }^{23}$.

Three different publications analyzed a specific group at high risk for the germline mutation in the BRCAl/2 genes: Ashkenazi Jews ${ }^{24-26}$. The studies assessed specific sequencing for founder mutations. Thus, Rubinstein et al. ${ }^{25}$ concluded that the screening program for the germline mutation increased survival at an acceptable cost. One limitation of this study, which focused entirely on ovarian cancer, was the lack of strategies to reduce the risk of breast cancer ${ }^{25}$. Manchanda et al. ${ }^{24}$, in turn, verified that a population-based screening strategy could save money and promote greater effectiveness by performing genetic tests only on people with a family history of malignant neoplasm. Finally, Grann et al. ${ }^{26}$ showed the superiority of combined surgery over exclusive mastectomy, exclusive salpingo-oophorectomy and the usual practice of watching and waiting for this population.

Other studies have assessed preventative strategies for individuals who carry the germline mutation in the BRCA1 and BRCA2 genes ${ }^{27-29}$. Thus, the study conducted by Anderson et al. ${ }^{29}$ showed a favorable incremental cost-effectiveness for the combination of bilateral prophylactic mastectomy and risk-reducing salpingo-oophorectomy. Another publication, which assessed preventative strategies for carriers of a mutation in the BRCA1 gene, reached a similar conclusion, pointing out that salpingo-oophorectomy, with or without bilateral prophylactic mastectomy, should be cost effective ${ }^{28}$. Similarly, Grann et al. ${ }^{27}$ suggested that, for carriers of a germline mutation in the $B R C A 1 / 2$ genes, prophylactic surgery is cost effective in comparison with chemoprevention and screening.

Therefore, the overall verdict of this study is that the program for diagnosing a germline mutation in the BRCAI/2 genes and for preventative strategies should be considered cost effective when its impact on family members of patients diagnosed with ovarian cancer is assessed. Different studies published in the literature have also shown the cost effectiveness of performing genetic tests and of risk-reducing surgical procedures.

One potential limitation of this study is the use of estimates and probabilities from international observational studies, since national data was unavailable. The use of billing information may also have caused distortions because of potential discrepancies regarding the cost of procedures. However, this perspective has the advantage of representing the actual payments made by the National Health Service in the federal domain.

Finally, the determination of the incremental cost-effectiveness ratio, even though it is very useful for informed decision-making, is not enough for the incorporation of technologies into the National Health System ${ }^{15}$. That decision can be influenced by many variables, such as political interest and priorities, social preferences, concerns about equity, financial availability, and budgetary impact. Thus, one possible ramification of this study would be the need to analyze the budgetary impact of turning the program into one of the country's health policies. Although the technology is considered cost effective, it is essential to know how much money the program would cost if it were offered by the National Health System to the Brazilian population. Such an analysis could guide decision-making and public policies for conditions such as ovarian cancer, which are highly lethal and often diagnosed quite late.

\section{REFERENCES}

1. Instituto Nacional de Câncer José Alencar Gomes da Silva, Coordenação de Prevenção e Vigilância. Estimativa 2016: incidência de câncer no Brasil. Rio de Janeiro: INCA; 2015 [cited 2017 Oct 16]. Available from: http://www.inca.gov.br/bvscontrolecancer/publicacoes/edicao/Estimativa_2016.pdf 
2. Ministério da Saúde (BR), DATASUS. Sistema de Informação sobre Mortalidade - SIM. Brasília (DF); c2008 [cited 2017 Nov 29]. Available from: http://www2.datasus.gov.br/DATASUS/index.php?area=060701

3. Cannistra SA. Cancer of the ovary. N Engl / Med. 2004;351(24):2519-29. https://doi.org/10.1056/NEJMra041842

4. Roett MA, Evans P. Ovarian cancer: an overview. Am Fam Physician. 2009;80(6):609-16.

5. Pal T, Permuth-Whey J, Betts JA, Krischer JP, Fiorica J, Arango $\mathrm{H}$, et al. BRCA1 and BRCA2 mutations account for a large proportion of ovarian carcinoma cases. Cancer. 2005;104(12):2807-16. https://doi.org/10.1002/cncr.21536

6. Maistro S, Teixeira N, Encinas G, Katayama MLH, Niewiadonski VDT, Cabral LG, et al. Germline mutations in BRCA1 and BRCA2 in epithelial ovarian cancer patients in Brazil. BMC Cancer. 2016;16(1):934. https://doi.org/10.1186/s12885-016-2966-x

7. Weissman SM, Weiss SM, Newlin AC. Genetic testing by cancer site: ovary. Cancer J. 2012;18(4):320-7. https://doi.org/10.1097/PPO.0b013e31826246c2

8. National Comprehensive Cancer Network. Guidelines for detection, prevention, and risk reduction genetic/familial high-risk assessment: breast and ovarian. Fort Washington: NCCN; 2016 [cited 2017 Oct 16]. v.2. Available from: https://www.nccn.org/professionals/physician_gls/default.aspx\#detection

9. Esserman L, Kaklamani V. Lessons learned from genetic testing. JAMA. 2010;304(9):1011-2. https://doi.org/10.1001/jama.2010.1263

10. Manchanda R, Abdelraheim A, Johnson M, Rosenthal AN, Benjamin E, Brunell C, et al. Outcome of risk-reducing salpingo-oophorectomy in BRCA carriers and women of unknown mutation status. Obstet Gynecol. 2011;118(7):814-24. https://doi.org/10.1111/j.1471-0528.2011.02920.x

11. Buys SS, Partridge E, Black A, Johnson CC, Lamerato L, Isaacs C, et al. Effect of screening on ovarian cancer mortality: the Prostate, Lung, Colorectal and Ovarian (PLCO) Cancer Screening Randomized Controlled Trial. JAMA. 2011;305(22):2295-303. https://doi.org/10.1001/jama.2011.766

12. Teixeira N, Maistro S, Estevez Diz MP, Mourits MJ, Oosterwijke JC, Folgueira MAK, et al. Predictability of BRCA1/2 mutation status in patients with ovarian cancer: how to select women for genetic testing in middle-income countries. Maturitas. 2017;105:113-8. https://doi.org/10.1016/j.maturitas.2017.06.002

13. Banco Central do Brasil. Cotações e boletins de taxa de câmbio [cited 2017 Oct 16]. Available from: https://www4.bcb.gov.br/pec/taxas/port/ptaxnpesq.asp?id=txcotacao

14. Ministério da Saúde (BR), DATASUS. SIGTAP - Sistema de Gerenciamento da Tabela de Procedimentos, Medicamentos, Órteses, Próteses e Materiais Especiais do Sistema Único de Saúde. Brasília (DF); s.d. [cited 2017 Oct 16]. Available from: http://sigtap.datasus.gov.br/tabela-unificada/app/sec/inicio.jsp Brasil

15. Ministério da Saúde (BR), Secretaria de Ciência, Tecnologia e Insumos Estratégicos, Departamento de Ciência e Tecnologia. Diretrizes metodológicas: diretriz de avaliação econômica. 2.ed. Brasília (DF); 2014 [cited 2017 Oct 16]. Available from: http://bvsms.saude. gov.br/bvs/publicacoes/diretrizes_metodologicas_diretriz_avaliacao_economica.pdf

16. Woods B, Revill P, Sculpher M, Claxton K. Country-level cost- effectiveness thresholds: initial estimates and the need for further research.. York (UK): Centre for Health Economics, University of York; 2015 [cited 2017 Oct 16]. (CHE Research Paper, 109). Available from: https://econpapers.repec.org/paper/chyrespap/109cherp.htm

17. Chen S, Parmigiani G. Meta-analysis of BRCA1 and BRCA2 penetrance. J Clin Oncol. 2007;25(11):1329-33. https://doi.org/10.1200/JCO.2006.09.1066

18. Metcalfe KA, Birenbaum-Carmeli D, Lubinski J, Gronwald J, Lynch H, Moller P, et al; Hereditary Breast Cancer Clinical Study Group. International variation in rates of uptake of preventive options in BRCA1 and BRCA2 mutation carriers. Int / Cancer. 2008;122(9):2017-22. https://doi.org/10.1002/ijc.23340

19. De Felice F, Marchetti C, Musella A, Palaia I, Perniola G, Musio D, et al. Bilateral risk-reduction mastectomy in BRCA1 and BRCA2 mutation carriers: a meta-analysis. Ann Surg Oncol. 2015;22(9):2876-80. https://doi.org/10.1245/s10434-015-4532-1

20. Rebbeck TR, Kauff ND, Domchek SM. Meta-analysis of risk reduction estimates associated with risk-reducing salpingo-oophorectomy in BRCA1 or BRCA2 mutation carriers. J Natl Cancer Inst. 2009;101(2):80-7. https://doi.org/10.1093/jnci/djn442 
21. Rudmik L, Drummond M. Health economic evaluation: important principles and methodology. Laryngoscope. 2013;123(6):1341-7. https://doi.org/10.1002/lary.23943

22. Kwon JS, Daniels MS, Sun CC, Lu KH. Preventing future cancers by testing women with ovarian cancer for BRCA mutations. J Clin Oncol. 2010;28(4):675-82. https://doi.org/10.1200/JCO.2008.21.4684

23. Holland ML, Huston A, Noyes K. Cost-effectiveness of testing for breast cancer susceptibility genes. Value Health. 2009;12(2):207-16. https://doi.org/10.1111/j.1524-4733.2008.00418.xA

24. Manchanda R, Legood R, Burnell M, McGuire A, Raikou M, Loggenberg K, et al. Cost-effectiveness of population screening for BRCA mutations in Ashkenazi Jewish women compared with family history-based testing. I Natl Cancer Inst. 2015;107(1):380. https://doi.org/10.1093/jnci/dju380

25. Rubinstein WS, Jiang H, Dellefave L, Rademaker AW. Cost-effectiveness of population-based BRCA1/2 testing and ovarian cancer prevention for Ashkenazi Jews: a call for dialogue. Genet Med. 2009;11(9):629-39. https://doi.org/10.1097/GIM.0b013e3181afd322

26. Grann VR, Whang WS, Jacobson JS, Heitjan DF, Antman KH, Neugut AI. Benefits and costs of screening Ashkenazi Jewish women for BRCA1 and BRCA2. J Clin Oncol. 1999;17(2):494-500. https://doi.org/10.1200/JCO.1999.17.2.494

27. Grann VR, Patel PR, Jacobson JS, Warner E, Heitjan DF, Ashby-Thompson M, et al. Comparative effectiveness of screening and prevention strategies among BRCA1/2-affected mutation carriers. Breast Cancer Res Treat. 2011;125(3):837-47. https://doi.org/10.1007/s10549-010-1043-4

28. Norum J, Hagen AI, Mæhle L, Apold J, Burn J, Møller P. Prophylactic bilateral salpingooophorectomy (PBSO) with or without prophylactic bilateral mastectomy (PBM) or no intervention in BRCA1 mutation carriers: a cost-effectiveness analysis. Eur J Cancer. 2008;44(7):963-71. https://doi.org/10.1016/j.ejca.2008.02.025

29. Anderson K, Jacobson JS, Heitjan DF, Zivin JG, Hershman D, Neugut AI, et al. Cost-effectiveness of preventive strategies for women with a BRCA1 or a BRCA2 mutation. Ann Intern Med. 2006;144(6):397-406.

30. Ferlay J, Soerjomataram I, Ervik M, Dikshit R, Eser S, Mathers C, et al, editors. GLOBOCAN 2012: estimated cancer incidence and mortality and prevalence worldwide in 2012 v1.0. Lyon (FR): International Agency for Research on Cancer; 2013 [cited 2015 Jun 11]. (IARC CancerBase, 11). Available from: http://publications.iarc.fr/Databases/larc-Cancerbases/Globocan-2012Estimated-Cancer-Incidence-Mortality-And-Prevalence-Worldwide-In-2012-V1-0-2012

Authors' Contribution: Study design and planning: MCAR, AGC, PCS, HMDN, MDPED, MAAKF, SM, GHB. Data collection, analysis and interpretation: MCAR, AGC, PCS, HMDN, MDPED. Writing of the manuscript: MCAR, AGC, PCS, HMDN, MDPED, MAAKF, SM, GHB. All the authors approved the final version of the manuscript and take public responsibility for its content..

Conflict of Interest: The authors declare no conflict of interest. 